WSRC-TR-2002-00570, Revision 0

December 3, 2002

Key Words: PUREX Waste

Solidification

Organic Waste

Organic Sorbents

Retention: Permanent

\title{
PUREX Organic Waste Solidification (U)
}

\author{
Author: Christine A. Langton \\ Westinghouse Savannah River Company \\ Savannah River Technology Center \\ Aiken, SC 29808
}

Report Date: December 3, 2002

Westinghouse Savannah River Company

Savannah River Site

Aiken, SC 29808

Prepared for the U.S. Department of Energy Under

Contract Number DE-AC09-96SR18500

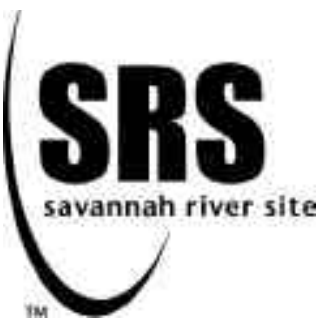


This document was prepared in conjunction with work accomplished under Contract No. DE-AC09-96SR18500 with the U. S. Department of Energy.

\section{DISCLAIMER}

This report was prepared as an account of work sponsored by an agency of the United States Government. Neither the United States Government nor any agency thereof, nor any of their employees, makes any warranty, express or implied, or assumes any legal liability or responsibility for the accuracy, completeness, or usefulness of any information, apparatus, product or process disclosed, or represents that its use would not infringe privately owned rights. Reference herein to any specific commercial product, process or service by trade name, trademark, manufacturer, or otherwise does not necessarily constitute or imply its endorsement, recommendation, or favoring by the United States Government or any agency thereof. The views and opinions of authors expressed herein do not necessarily state or reflect those of the United States Government or any agency thereof.

This report has been reproduced directly from the best available copy.

Available for sale to the public, in paper, from: U.S. Department of Commerce, National Technical Information Service, 5285 Port Royal Road, Springfield, VA 22161, phone: (800) 553-6847, fax: (703) 605-6900

email: orders@ntis.fedworld.gov

online ordering: http://www.ntis.gov/help/index.asp

Available electronically at http://www.osti.gov/bridge

Available for a processing fee to U.S. Department of Energy and its contractors, in paper, from: U.S. Department of Energy, Office of Scientific and Technical Information, P.O. Box 62, Oak Ridge, TN 37831-0062,

phone: (865)576-8401,

fax: (865)576-5728

email: $\underline{\text { reports@ adonis.osti.gov }}$ 
WSRC-TR-2002-00570, Revision 0

December 3, 2002

Page 3 of 22

\section{REVIEWS AND APPROVALS}
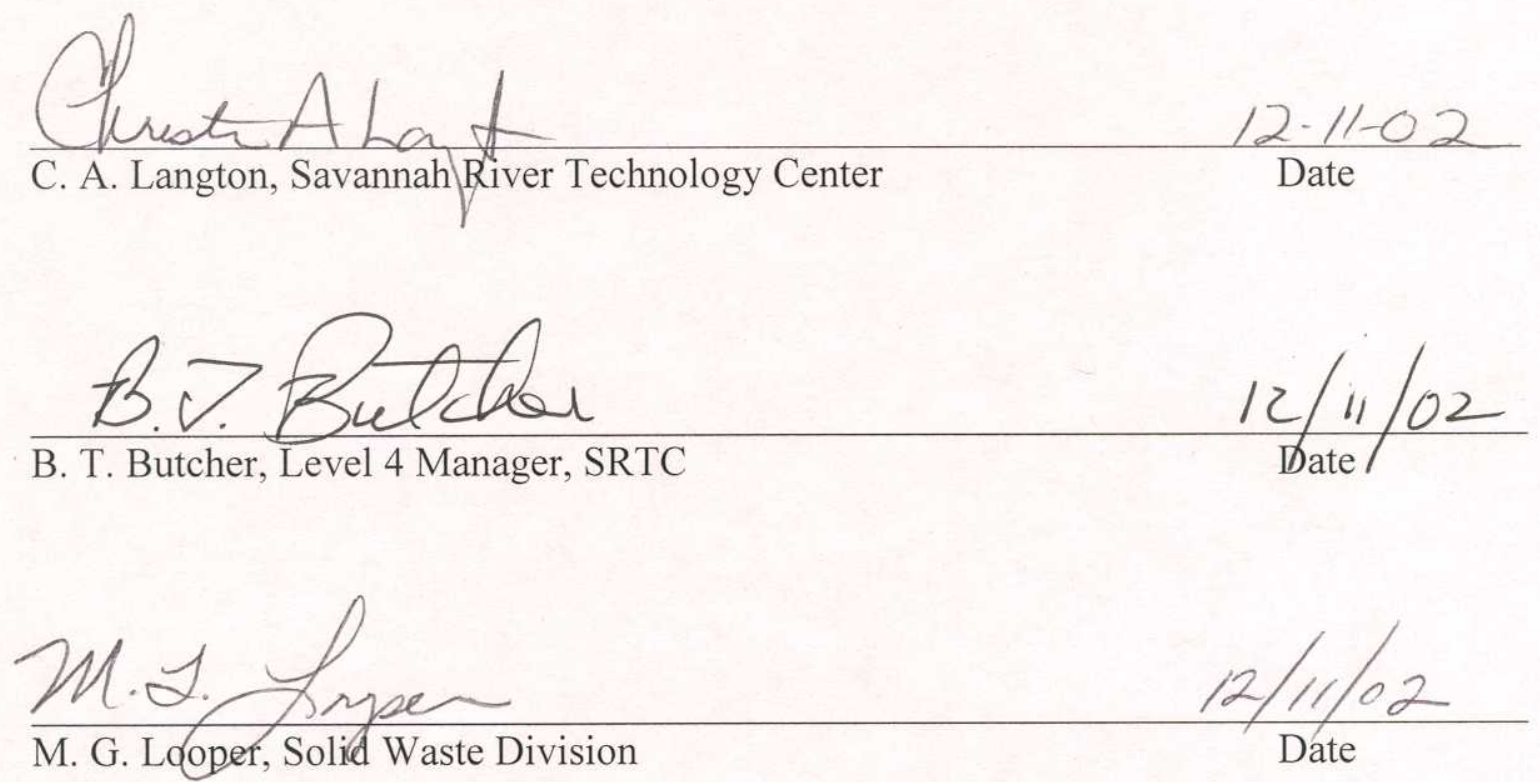
WSRC-TR-2002-00570, Revision 0

December 3, 2002

Page 4 of 22

\section{TABLE OF CONTENTS}

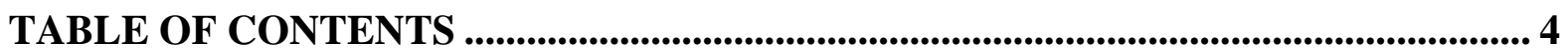

1.0 SUMMARY ............................................................................................................................ 5

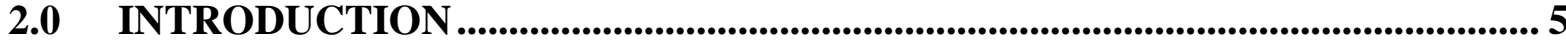

2.1 Background .............................................................................................................. 5

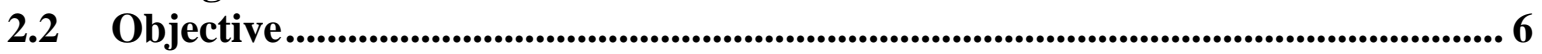

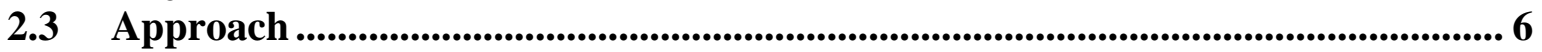

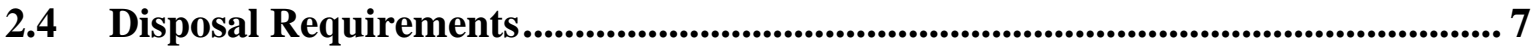

3.0 EXPERIMENTAL PROCEDURES ................................................................ 7

3.1 Sorbent and Waste Loading Selection .............................................................. 7

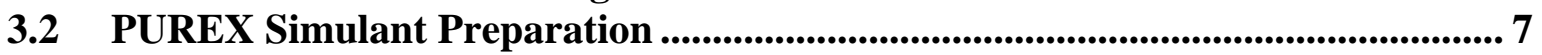

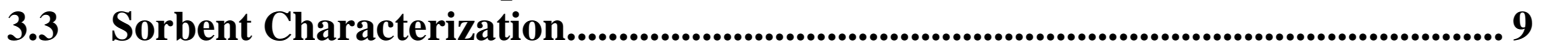

3.4 Waste Form Preparation ..................................................................................9

3.5 TCLP Extraction and Analyses for Regulatory Classification ............................ 9

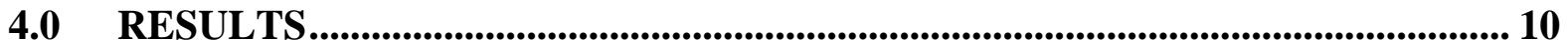

4.1 Sorbent Characterization................................................................................................. 10

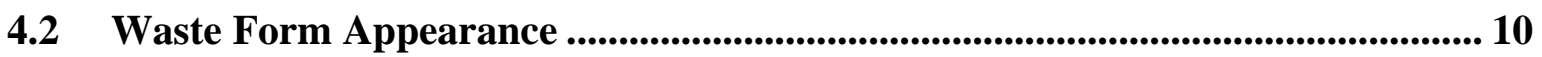

4.3 Regulatory Classification of the PUREX Waste and Solidified Waste Forms .. 10

4.4 TCLP Results .................................................................................................................... 18

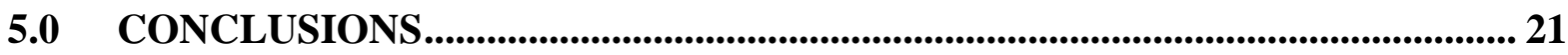

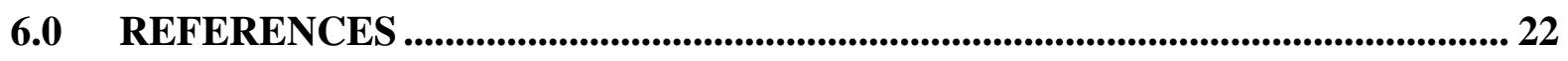




\subsection{SUMMARY}

Approximately 38,000 gallons of PUREX waste is currently stored in H-Area at the New Solvent Storage Facility (NSST). About 25,000 gallons of this waste is an organic liquid containing solvents from the PUREX process. This waste was originally planned for treatment at the Consolidated Incineration Facility (CIF). However, because of the high cost to restart and operate the CIF, a more cost effective treatment alternative is desired. The goal is a waste treatment producing an acceptable waste form for final disposal either at the SRS low-level waste landfill in E-Area or at the Nevada Test Site (NTS).

This report summarizes the results of a feasibility study that evaluated solidification as an alternative treatment for organic waste. Six sorbents (four organic polymers and two clay products) were tested for solidification of simulated PUREX organic waste. Waste forms containing actual PUREX waste from Tank 35 were prepared to confirm the simulant. Mixing and general appearance of the waste forms prepared with the simulant and the actual waste were indistinguishable in the laboratory experiments. Waste forms were prepared with two waste loadings, 50 and 66 weight percent PUREX, referred to as 1:1 and 1:2 waste loadings, respectively. All of the six sorbents resulted in waste forms that meet the disposal criteria, including regulatory treatment requirements, for the SRS E-Area disposal facility and the Nevada Test Site. Four of the six sorbents, Imbiber Beads, Nochar A610, Petroset II and Petroset II Granular are recommended for further testing, including optimization of the waste form formulation and equipment scale-up testing with simulated waste.

Imbiber Beads Nuclear Grade was eliminated for further testing because it contains a wicking agent that is hydrophyllic and swells upon absorption of water. This feature is undesirable from the standpoint of packaging, storage and transportation. The Nochar A650 sorbent was eliminated because it reacts with the organic components in the PUREX and undergoes physical and chemical changes upon aging. (This polymer is plasticized by the PUREX waste.)

Further selection of a material for solidifying the spent PUREX waste will depend on optimizing the waste form properties and on scale-up test results using simulated and actual waste. The two organic sorbents Imbiber Beads and Nochar A610 result in light weight particulate waste forms that may offer some processing advantages not apparent in laboratory-scale batches.

\subsection{INTRODUCTION}

\subsection{Background}

Currently about 38,000 gallons of legacy PUREX waste are stored in two tanks, Tank-33 and -35, at the New Solvent Storage Tank (NSST) Facility at Savannah River Site (SRS). These tanks contain approximately 25,000 gallons of spent PUREX solvent (organic liquid) and about 13,000 gallons of aqueous waste. The PUREX solvent was used in organic-aqueous isotope separation processes in Fand $\mathrm{H}$-Areas. The aqueous fraction is primarily wash water generated when the organic liquid was transferred from old underground storage tanks in E-Area to the new tanks in H-Area. 
The spent PUREX waste consists of two immiscible phases, a lower density organic liquid containing n-paraffins and tributyl phosphate in addition to aromatic hydrocarbons and amine compounds, and an aqueous phase containing primarily water and dibutyl phosphate. This waste is classified as low-level radioactive mixed waste because analyses of some samples from the old tanks indicated several hazardous constituents, such as mercury, chromium lead, silver, benzene, and trichloroethylene were present in concentrations above the limits for RCRA characteristically hazardous waste.

Thermal oxidation in the CIF is currently identified as the treatment of the spent PUREX waste. However, at the present time the CIF is not operating, and SRS is pursuing altenatives to treatment in the CIF because of the high cost of restarting the facility to treat the PUREX waste.

This report addresses the organic phase of the PUREX waste and describes stabilization technologies resulting in solid, nonhazardous waste forms suitable for low-level shallow land disposal at SRS (EArea) or at the Nevada Test Site (NTS). Details of the task plan are described in a separate report [1].

\subsection{Objective}

The objectives of this study were to evaluate solidification/stabilization as an alternative treatment technology for the organic phase of the SRS spent PUREX waste using simulated waste, and to evaluate waste forms prepared with actual spent organic PUREX waste for regulatory classification. The objective of the waste treatment is to produce a waste form that meets the requirements for final shallow land disposal at SRS or at the NTS. More specifically, the task included the following:

- $\quad$ Prepare simulated waste based on analyses of the Tank 33 and 35 material.

- Identify potential solidification/stabilization reagents for treatment of PUREX organic waste.

- Conduct scoping studies to evaluate potential solidification/stabilization reagents using simulated PUREX waste.

- Confirm that the simulated waste approximates the actual waste with respect to waste form testing.

- Evaluate PUREX waste-sorbent interactions.

- Evaluate leaching properties for waste forms prepared with actual spent PUREX waste.

\subsection{Approach}

The approach was to conduct waste formulation studies using simulated spent PUREX waste and commercially available organic sorbents to produce solid waste forms. Both organic polymer sorbents and inorganic sorbents were included in the test matrix. Since the results of this testing were promising, further testing with actual organic PUREX waste was conducted to confirm the simulant testing and evaluate if the stabilization treatments meets regulatory requirements for disposal. 


\subsection{Disposal Requirements}

Once the PUREX organic waste is treated to meet all hazardous waste regulatory requirements, the waste form must still meet acceptance criteria for disposal as a low-level waste at either SRS or the Nevada Test Site (NTS). The Low-Level Waste Acceptance Criteria (WAC) for E-Area and for the NTS were reviewed to determine acceptability of a solidified/stabilized organic waste form for disposal [2 and 3, respectively]. Currently, the SRS E-Area WAC does not include solidified PUREX waste forms as accepted waste streams. Consequently, as a new waste stream, the solidified PUREX waste must undergo the SW Waste Certification Process to determine whether it is acceptable for E-Area disposal.

The NTS requires the approved waste generator to submit a waste profile (characterization) for consideration. In addition, packaging and transportation requirements for shipping waste from SRS to NTS must be identified and addressed if solidified PUREX waste is sent off-site.

\subsection{EXPERIMENTAL PROCEDURES}

\subsection{Sorbent and Waste Loading Selection}

Solidification reagents for organic liquids were identified from vendor literature and from information obtained from personnel at Chem-Nuclear, SC, the Nevada Test Site, NV, Envirocare, UT and British Nuclear Fuels, Limited (BNFL), Sellefield UK. Materials used for solidifying organic liquids are commonly referred to as sorbents.

Three vendors, Nochar, Inc., Imbibitive Technologies, Inc., and Fluid Tech, Inc. market sorbents for organic waste treatment. The Nochar and Imbiber sorbents are organic polymers. The Fluid Tech, Inc. sorbents are modified inorganic clays (sodium montmorillonites). Product samples and technical information were obtained from each of these vendors. Nochar Inc. provided a technical representative to assist in the initial product screening. The sorbents/solidifying reagents tested in this study are listed in Table 3-1.

The amount of each reagent added was based on vendor data for waste treatment to effectively immobilize the hazardous constituents. Optimizing the formulation for each sorbent to determine the maximum achievable waste loading was not an objective of this study. The proportioning was conducted on a weight rather than a volumetric basis because weights were more accurate, consistent, and convenient for laboratory work.

\subsection{PUREX Simulant Preparation}

Simulated PUREX waste was prepared from reagent chemicals and was used for the formulation testing. The simulant composition was based on analyses of the actual waste. The ingredients and proportions of the simulant used is shown in Table 3-2. 
Table 3-1. List of sorbents and waste loading ratios

\begin{tabular}{|c|c|c|}
\hline \multirow{2}{*}{$\begin{array}{l}\text { Vendor/Product } \\
\text { Imbibitive Technologies, Inc. }\end{array}$} & \multicolumn{2}{|c|}{$\begin{array}{c}\text { Waste Loading* } \\
\text { Reagent : Simulated PUREX } \\
\text { (by weight) }\end{array}$} \\
\hline & & \\
\hline $\begin{array}{l}\text { Imbiber Beads }{ }^{\mathrm{TM}} \text { (organic polymer) } \\
\text { (alkylstyrene copolymer from MSDS) }\end{array}$ & $1: 1$ & $1: 2$ \\
\hline $\begin{array}{l}\text { Imbiber Beads NG }{ }^{\mathrm{TM}} \text { (organic polymer in Imbiber } \\
\text { Beads plus a polyethylene wicking agent) }\end{array}$ & $1: 1$ & $1: 2$ \\
\hline \multicolumn{3}{|l|}{ Nochar, Inc. } \\
\hline Nochar A-610 Petrobond ${ }^{\mathrm{TM}}$ (organic polymer) & $1: 1$ & $1: 2$ \\
\hline Nochar A-650 Petrobond (organic polymer) & $1: 1$ & $1: 2$ \\
\hline \multicolumn{3}{|l|}{ Fluid Tech, Inc. } \\
\hline $\begin{array}{l}\text { Petroset II }{ }^{\mathrm{TM}} \text { (organo-clay intercalated with } \\
\text { quaternary ammonium amine) }\end{array}$ & $1: 1$ & $1: 2$ \\
\hline Petroset II Granular ${ }^{\mathrm{TM}}$ (same as Petroset II) & $1: 1$ & $1: 2$ \\
\hline
\end{tabular}

* Sorbent-to-waste ratio of 1:1 represents a $50 \%$ waste loading by weight, and a 1:2 ratio represents a $66 \%$ waste loading by weight.

Table 3-2. Composition of simulated organic PUREX waste based on Tank 33 and 35 averages.

\begin{tabular}{|l|c|c|c|c|c|}
\hline Ingredients & $\begin{array}{c}\text { Flash Point } \\
\left({ }^{\circ} \mathbf{C}\right)\end{array}$ & $\begin{array}{c}\text { Ignition } \\
\text { Temp. }\left({ }^{\circ} \mathbf{C}\right)\end{array}$ & $\begin{array}{c}\text { NFPA } \\
\text { Chemcial } \\
\text { Hazards } \\
\text { Rating* }\end{array}$ & Spg & $\begin{array}{c}\text { Amount } \\
(\mathbf{w t . ~ \% )}\end{array}$ \\
\hline Tributyl Phosphate & 193 & & $2 / 1 / 0$ & 0.979 & 17.60 \\
\hline $\begin{array}{l}\text { Aliphatic hydrocarbon } \\
(\mathrm{n} \text {-paraffin) }\end{array}$ & & & & & \\
\hline Undecane & 60 & & & 0.7402 & 8.45 \\
\hline Dodecane & 71 & 200 & $2 / 2 / 1$ & 0.748 & 8.45 \\
\hline Tridecane & 79 & 201 & $2 / 2 / 0$ & 0.757 & 8.45 \\
\hline Tetradecane & 101 & 204 & & 0.763 & 8.45 \\
\hline Aromatic hydrocarbon & & & & & \\
\hline Diethylbenzene & 57 & & & 0.870 & 21.00 \\
\hline Di-isopropylbenzene & 76 & & & 0.857 & 21.00 \\
\hline Aliphatic amine & & & & & \\
\hline Di-n-octylamine & $>110$ & & $2 / 2 / 0$ & 0.799 & 6.60 \\
\hline Total & & & & & 100.00 \\
\hline
\end{tabular}


* See SRS Asset Management Manual 3B Section 2-3 for the key to the hazard ratings [4].

\subsection{Sorbent Characterization}

Physical and chemical properties of the six sorbents were measured to obtain information on raw materials handling, waste form processing, and PUREX waste-sorbent interactions. Macroscopic and microscopic descriptions were recorded and bulk densities were measured. Data generated from Thermal Gravimetric Analysis (TGA), Differential Thermal Analysis (DTA), and Fourier Transform Infrared (FTIR) Spectroscopy were used to obtain approximate polymeric compositions and structures of the organic reagents. X-ray diffraction (XRD) was used to obtain information on the mineralogy and basal spacing of the inorganic clay sorbent.

\subsection{Waste Form Preparation}

The order of mixing and the need for stirring were evaluated. Vendors recommended the addition of the liquid to the sorbent without mixing. This technique resulted in very inhomogeneous products that were not appropriate for comparison testing. Consequently for the purpose of this study, the waste forms were prepared by adding the sorbent to the organic liquid waste while mixing. The exception was the preparation of the leaching samples with actual Tank 35 waste. Mixing was performed after the sorbent was added to the waste. This technique also resulted in an even distribution of the liquid waste and a uniform product. Laboratory batches ranged from 50 to 150 grams. The largest batches (150 grams) were equivalent to about 500 cubic centimeters.

After mixing, the waste forms were placed in sealed glass containers for curing/aging prior to testing. All test specimens were cured for a minimum of seven days at room temperature prior to evaluation.

\subsection{TCLP Extraction and Analyses for Regulatory Classification}

The TCLP extraction procedure is used to determine the soluble hazardous metals in a waste or waste form for the purpose of regulatory classification and determination of disposal options. For this test, the alkalinity of the sample must first be determined in order to select the extraction fluid. The PUREX waste forms are not alkaline so extraction Fluid \#1, which is a sodium acetate solution with a $\mathrm{pH}$ of 4.93 , was determined to be appropriate. (Samples with a high alkalinity use extraction Fluid \#2, which is a dilute acetic acid solution with a $\mathrm{pH}$ of 2.8.) The samples were size reduced to pass a minus $3 / 8$ inch sieve and then tumbled in the appropriate extraction fluid for 18 hours.

The radioactive PUREX waste forms were extracted by the Savannah River Technology Center (SRTC). The hazardous metals were analyzed by ICP-MS (Ag, Ba, Cd, Cr, Pb), atomic absorption spectroscopy (As and $\mathrm{Se}$ ) and by mercury cold vapor extraction $(\mathrm{Hg})$. The metals that make up the RCRA underlying hazardous constituents (UHC) were analyzed by ICP-ES with the exception of thallium, Tl, which was analyzed by ICP-MS. The detection limits for the methods used to analyze these metals were below the RCRA Universal Treatment Standard Limits (UTS). Therefore, the results are adequate for planning and engineering purposes. Certified analyses are required for regulatory purposes. One waste form, the Petroset II with a 66 wt. \% loading was sent to GEL, Charleston for a certified analysis. 
In addition to the TCLP analysis for metal leachability, total benzene and total trichloroethylene concentrations were determined for the waste forms with 1:2 waste loadings [5]. The total benzene and TCE concentrations in these waste forms are 66 percent of the total concentrations in the PUREX organic waste. The Imbiber Beads, Petroset II and Petroset II Granular waste forms had very uniform waste distribution. Volatile organic analyses were performed by gas chromatographymass spectrometry (GC-MS). Samples were concentrated using a Dynamic Headspace concentrator (purge and trap) using a three stage trap. Internal standard and recovery surrogate compounds were added as specified in the laboratory protocol for volatile organics. The method detection limits for these organic components were well below the treatment standard values (UTS limits).

\subsection{RESULTS}

\subsection{Sorbent Characterization}

The physical properties of the various sorbents are described in Table 4-1. Micrographs of the sorbents are provided in Figure 4-1. Catalogue price information was obtained for some sorbents.

The basic compounds in the sorbents were identified in general terms to provide base line information for understanding the sorption properties/limitations of the sorbents and for predicting the effects of degradation and long-term performance of the waste forms. Techniques used to identify the sorbents included FTIR spectroscopy and TGA/DTA. The results are summarized in Table 4-2.

\subsection{Waste Form Appearance}

The PUREX waste forms were initially prepared with simulated PUREX waste. Photographs of the 1:1 and 1:2 waste loadings are shown in Figures 4-2 and 4-3, respectively. Photographs of some of the waste forms made with actual waste are shown in Figures 4-4 and 4-5. Waste forms prepared with actual Tank 35 waste appeared similar to those prepared with the simulated waste except for the color. The actual PUREX waste was medium to dark brown in color and resembled the simulated PUREX after it was irradiated with Co-60 gamma rays in the laboratory. The Tank 35 PUREX waste is yellow to brown in color as are the waste forms made from actual spent PUREX liquid. The simulated PUREX was clear and consequently the waste forms retain the color of the sorbent.

\subsection{Regulatory Classification of the PUREX Waste and Solidified Waste Forms}

The organic PUREX waste, designated SR-W045 in the SRS Site Treatment Plan, is classified as a mixed waste since it is radioactive and is also classified as a nonwastewater that displays hazardous characteristics per RCRA [6]. The RCRA D-codes listed in the Site Treatment Plan were assigned on the basis of analyses of waste samples collected from the old solvent tanks in E-Area. Analyses of samples recently collected from the organic waste in Tanks 33 and 35 are listed in Table 4-3, columns 2 and 3. These analytical results, plus process knowledge, are needed to determine the regulatory classification of the waste form. The metals and organics used to make the hazardous waste determination are listed in Group I, Table 4-3 as the RCRA Hazardous constituents. 
Table 4-1. Physical descriptions of the sorbents tested.

\begin{tabular}{|c|c|c|c|c|}
\hline Vendor/Product & $\begin{array}{l}\text { Estimated } \\
\text { Price }\end{array}$ & $\begin{array}{c}\text { Bulk } \\
\text { Density } \\
(\mathrm{g} / \mathrm{cc})^{*}\end{array}$ & $\begin{array}{c}\text { Particle Size } \\
\quad(\mathbf{m m})\end{array}$ & Visual Description \\
\hline $\begin{array}{l}\text { Imbibitive Inc./ } \\
\text { Imbiber Beads }{ }^{\mathrm{TM}} \\
\text { (alkylstyrene } \\
\text { copolymer) }\end{array}$ & $\begin{array}{l}\$ 3.55 / 1 \mathrm{~b} \\
\text { (bulk) }\end{array}$ & $\begin{array}{l}0.70 \\
+/-0.06\end{array}$ & $\begin{array}{l}\text { 125-420 um. } \\
\text { from MSDS }\end{array}$ & Spheres (clear) \\
\hline $\begin{array}{l}\text { Imbibitive } \\
\text { Technologies Inc./ } \\
\text { Imbiber Beads } \mathrm{NG}^{\mathrm{TM}} \\
\text { (alkylstyrene } \\
\text { copolymer plus } \\
\text { polyethylene } \\
\text { wicking agent) }\end{array}$ & & $\begin{array}{l}0.27 \\
+/-0.05\end{array}$ & $\begin{array}{l}\text { Spheres same as } \\
\text { Imbiber beads } \\
\text { Film material } \\
\text { (polyethylene) is } \\
\text { very thin and } \\
\text { hydrophillic }\end{array}$ & $\begin{array}{l}\text { At least } 3 \text { materials, spheres } \\
\text { wrapped in shredded } \\
\text { (feathery/lacy) material plus } \\
\text { a } 3^{\text {rd }} \text { material present as } \\
\text { angular chunks (may be the } \\
\text { same material as the film) } \\
\text { Some phase separation of } \\
\text { the spheres from the other } \\
\text { material. }\end{array}$ \\
\hline $\begin{array}{l}\text { Nochar Inc./ } \\
\text { Nochar A-610 }\end{array}$ & $\begin{array}{l}\$ 8 / \mathrm{lb} \\
(\$ 304 / \\
40 \mathrm{lb})\end{array}$ & $\begin{array}{l}0.24 \\
+/-0.03 \\
\end{array}$ & $\begin{array}{l}\text { Nodular material } \\
0.1 \text { to }>2 \mathrm{~mm} \text { in } \\
\text { size and stringers } \\
\text { up to } 1 \mathrm{~mm}\end{array}$ & $\begin{array}{l}\text { Irregular shaped particles } \\
\text { made up of connected } \\
\text { nodules (white, opaque) }\end{array}$ \\
\hline $\begin{array}{l}\text { Nochar Inc./ } \\
\text { Nochar A-650 }\end{array}$ & & $\begin{array}{l}0.38 \\
+/-0.02 \\
\end{array}$ & $<0.1$ to $0.5 \mathrm{~mm}$ & $\begin{array}{l}\text { Irregular grains, (colliform, } \\
\text { nodular) (white, opaque) }\end{array}$ \\
\hline $\begin{array}{l}\text { Fluid Tech Inc./ } \\
\text { Petroset II }\end{array}$ & $\$ 1.75 / \mathrm{lb}$ & $\begin{array}{l}0.52 \\
+/-0.04\end{array}$ & $\begin{array}{c}<0.01 \text { to }>0.03 \\
\mathrm{~mm}\end{array}$ & $\begin{array}{l}\text { Small agglomerates of } \\
\text { particles (gray to brown) }\end{array}$ \\
\hline $\begin{array}{l}\text { Fluid Tech.Inc./ } \\
\text { Petroset II } \\
\text { Granular }^{\mathrm{TM}}\end{array}$ & & $\begin{array}{l}0.65 \\
+/-0.15\end{array}$ & 0.05 to $0.2 \mathrm{~mm}$ & $\begin{array}{l}\text { Agglomerated particles } \\
\text { (dark olive black) }\end{array}$ \\
\hline
\end{tabular}

* Relatively small samples were used for the bulk density determinations. On this small-scale, sample preparation technique (sampling, degree of packing, etc.) for these compressible materials effects the results. 
WSRC-TR-2002-00570, Revision 0

December 3, 2002

Page 12 of 22

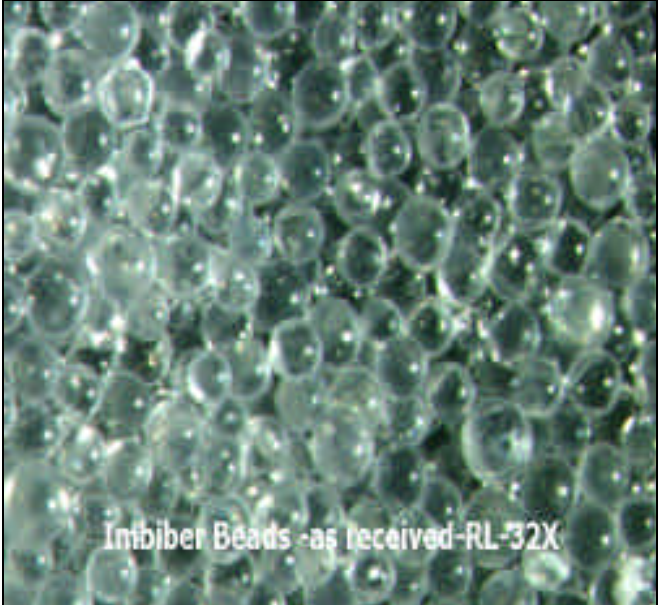

Imbiber Beads

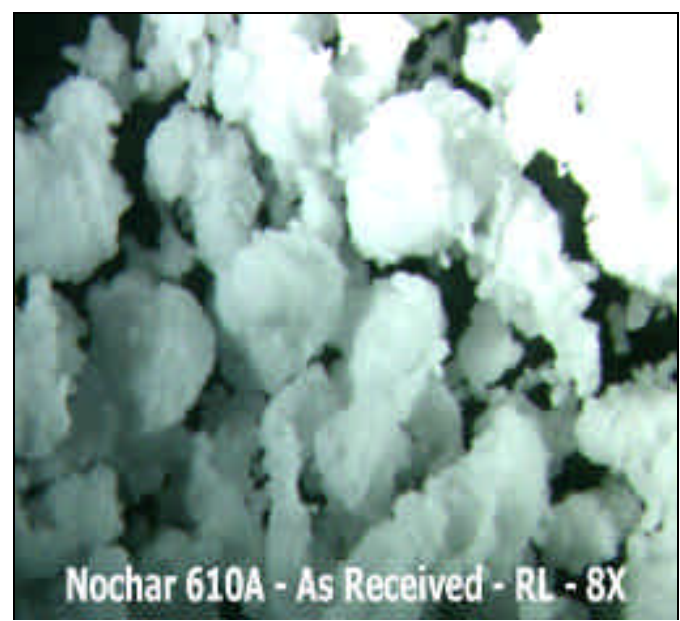

Nochar A610

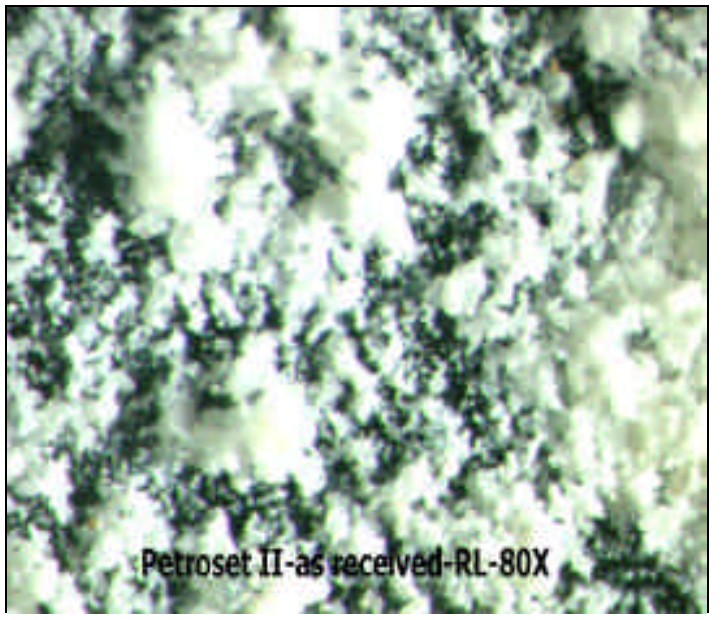

Petroset II

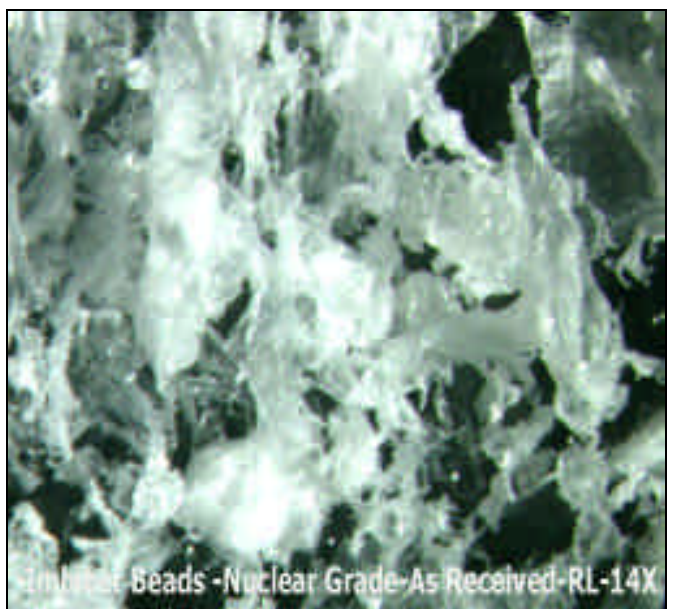

Imbiber Beads Nuclear Grade

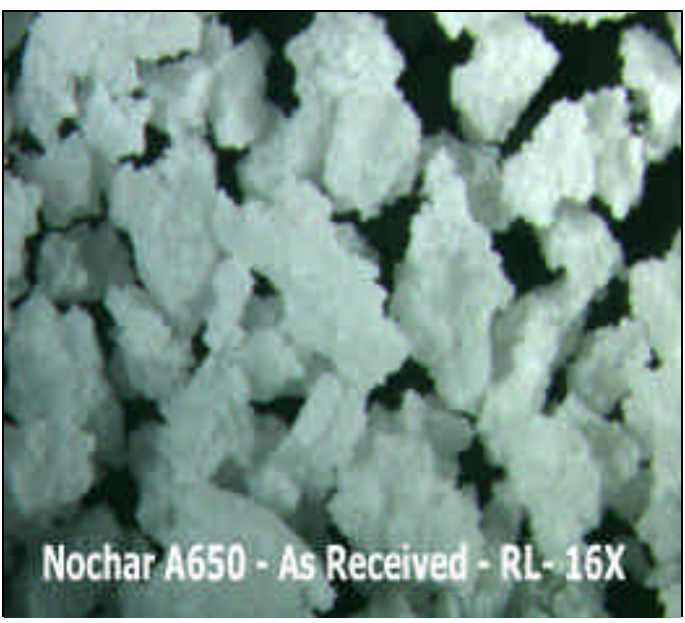

Nochar A650

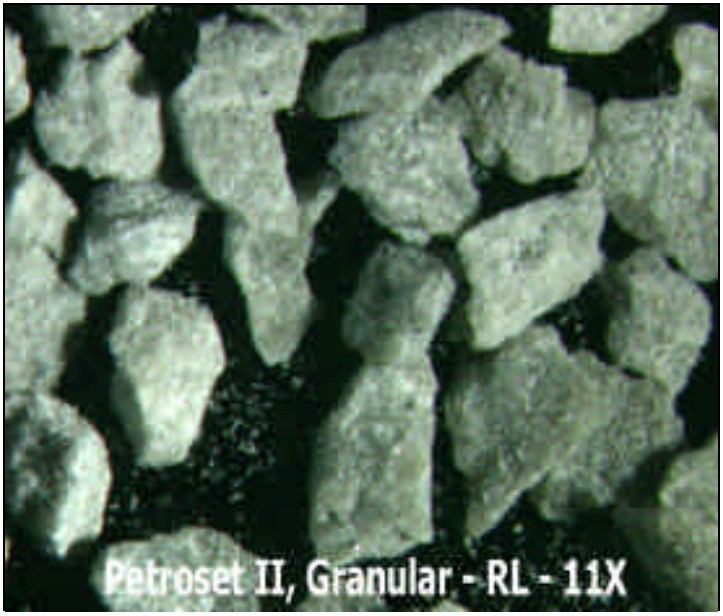

Petroset II Granular

Figure 4-1. Micrographs of the Sorbent Materials. (RL indicates reflected light. $X$ indicates the magnification) 
Table 4-2. Summary of phases identified in the sorbent materials evaluated for PUREX solidification and temperatures at which these phases decompose.

\begin{tabular}{|c|c|c|c|c|}
\hline \multirow[b]{2}{*}{ Vendor/Product } & \multirow[b]{2}{*}{ Components } & \multicolumn{3}{|c|}{ Component identification via three analytical methods } \\
\hline & & $\begin{array}{l}\text { Thermal Gravimetric } \\
\text { Analysis }\end{array}$ & $\begin{array}{l}\text { Fourier Transform Infared } \\
\text { Spectroscopy }\end{array}$ & X-Ray Diffraction \\
\hline $\begin{array}{l}\text { Nochar/ } \\
\text { A-610 Petrobond }\end{array}$ & $\begin{array}{l}\text { Copolymer of styrene, } \\
\text { butadiene and possibly } \\
\text { acrylates and pthalates }\end{array}$ & $\begin{array}{l}300-350^{\circ} \mathrm{C} \text { : acrylic acid and } \\
\text { styrenic acid volatilization } \\
525^{\circ} \mathrm{C} \text { : carbonization of the } \\
\text { polymer backbone }\end{array}$ & $\begin{array}{l}\text { Styrene: } 1610,1498,755 \text { and } \\
698 \mathrm{~cm}^{-1}, \text { butadiene: } 2924, \\
2856,1047,1033,560 \text { and } \\
1450 \mathrm{~cm}^{-1} \text { and possibly } \\
\text { acrylates (or pthalates) } 1723, \\
1183 \mathrm{~cm}^{-1}\end{array}$ & 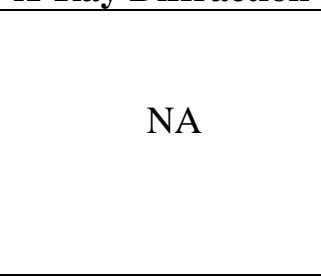 \\
\hline $\begin{array}{l}\text { Nochar/ } \\
\text { A-650 Petrobond }\end{array}$ & $\begin{array}{l}\text { Similar to A610 plus } \\
\text { calcium carbonate }\end{array}$ & $\begin{array}{l}400-450^{\circ} \mathrm{C} \text { : acrylic acid } \\
\text { styrenic acid volatilization } \\
500^{\circ} \mathrm{C} \text { : carbonization of } \\
\text { polymer backbone }\end{array}$ & $\begin{array}{l}\text { Same as Nochar A610, plus } \\
\text { calcium carbonate: } 1457 \text { and } \\
877 \mathrm{~cm}^{-1}\end{array}$ & NA \\
\hline $\begin{array}{l}\text { Imbibitive } \\
\text { Technologies Inc./ } \\
\text { Imbiber Beads }\end{array}$ & $\begin{array}{l}\text { Styrene, ethylene and } \\
\text { probably acrylate } \\
\text { copolymer }\end{array}$ & $\begin{array}{l}225-450^{\circ} \mathrm{C} \text { : acrylic and } \\
\text { styrenic acids volatilization } \\
>500^{\circ} \mathrm{C} \text { : carbonization of } \\
\text { polymeric backbone }\end{array}$ & $\begin{array}{l}\text { Crosslinked polystyrene resin } \\
\text { with carbonyl functional } \\
\text { groups, (possibly acrylate } \\
\text { groups) }\end{array}$ & NA \\
\hline $\begin{array}{l}\text { Imbibitive } \\
\text { Technologies Inc./ } \\
\text { Imbiber Beads Nuclear } \\
\text { Grade }\end{array}$ & $\begin{array}{l}\text { Same as Imbiber beads } \\
\text { plus polyethylene as a } \\
\text { separate phase }\end{array}$ & $\begin{array}{l}225-400^{\circ} \mathrm{C}: \text { acrylic and } \\
\text { styrenic acids volatilization } \\
450-500^{\circ} \mathrm{C} \text { carbonization of } \\
\text { polyethylene } \\
>500^{\circ} \mathrm{C} \text { : carbonization of } \\
\text { polymeric backbone }\end{array}$ & $\begin{array}{l}\text { Same as Imbiber beads plus } \\
\text { polyethylene as a second phase }\end{array}$ & NA \\
\hline $\begin{array}{l}\text { Fluid Tech/Petroset II } \\
\text { and Petroset II Granular }\end{array}$ & $\begin{array}{l}\text { Mixture of sodium } \\
\text { montmorillonite and } \\
\text { sodium } \\
\text { montmorillonite } \\
\text { intercalated with a } \\
\text { quaternary amine, plus } \\
\text { mineral impurities } \\
\text { (quartz, gypsum, halite) }\end{array}$ & $\begin{array}{l}181-300^{\circ} \mathrm{C} \text { : hydrocarbon } \\
\text { volatilization } \\
300->400^{\circ} \mathrm{C} \text { : hydrocarbon } \\
\text { volatilization } \\
>600^{\circ} \mathrm{C}: \mathrm{NO}_{2} \text { volatilization }\end{array}$ & $\begin{array}{l}\text { Montmorillonite clay plus tetra } \\
\text { hydrocarbons (C14) attached } \\
\text { to a nitrogen (amine). }\end{array}$ & $\begin{array}{l}\text { Sodium } \\
\text { montmorillonite, } \\
\text { modified sodium } \\
\text { montmorillonite, } \\
\text { plus (quartz, } \\
\text { gypsum, halite, etc.) }\end{array}$ \\
\hline
\end{tabular}


WSRC-TR-2002-00570, Revision 0

December 3, 2002

Page 14 of 22

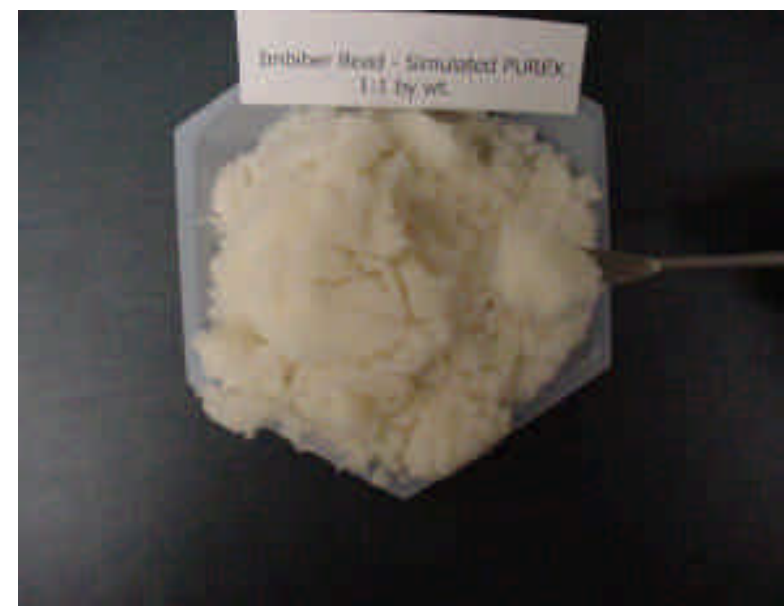

Imbiber

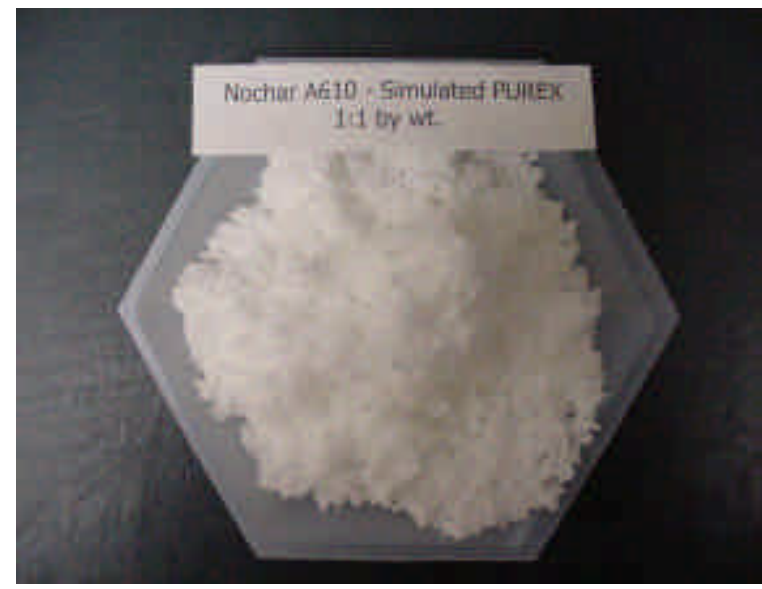

Nochar A610

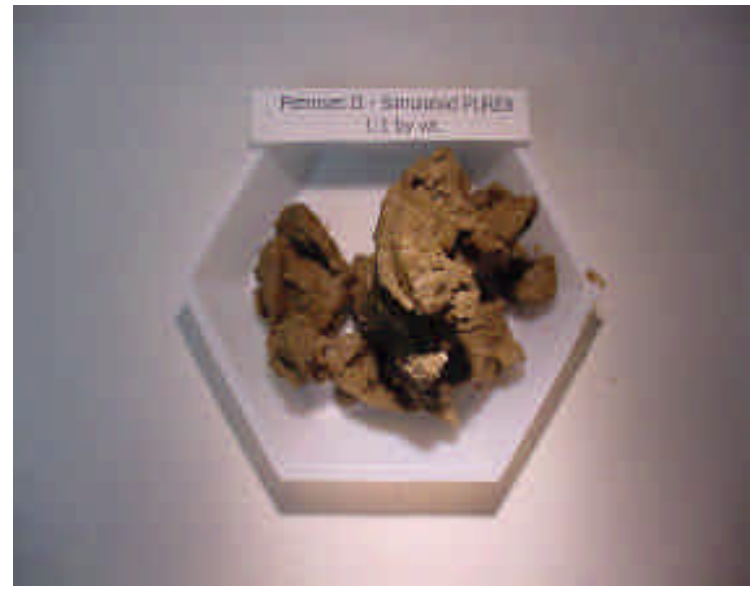

Petroset II

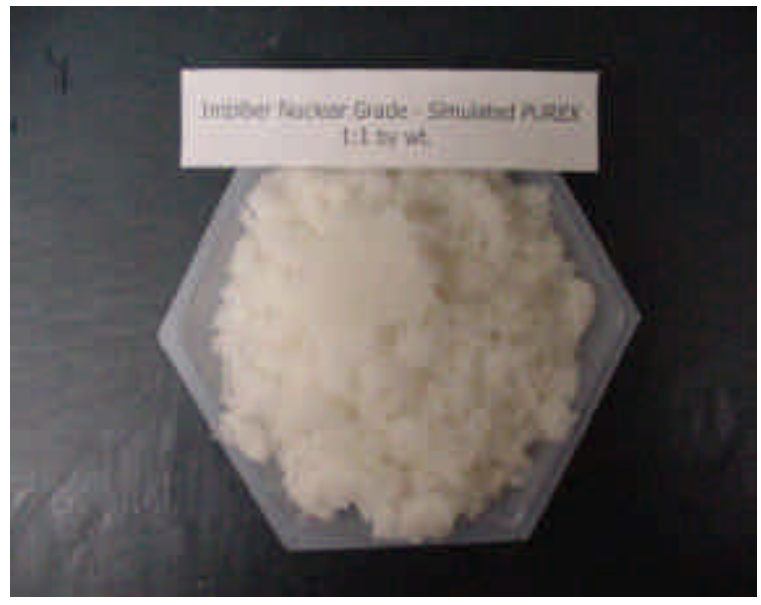

Imbiber Nuclear Grade

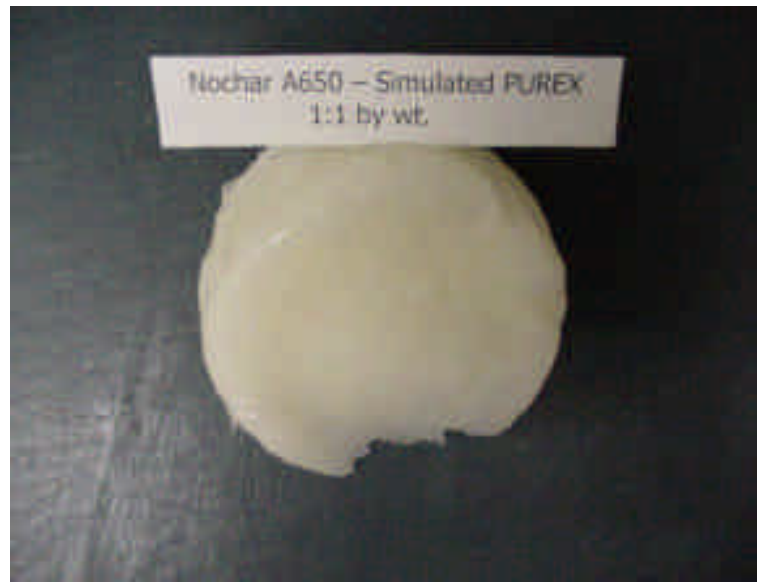

Nochar A650

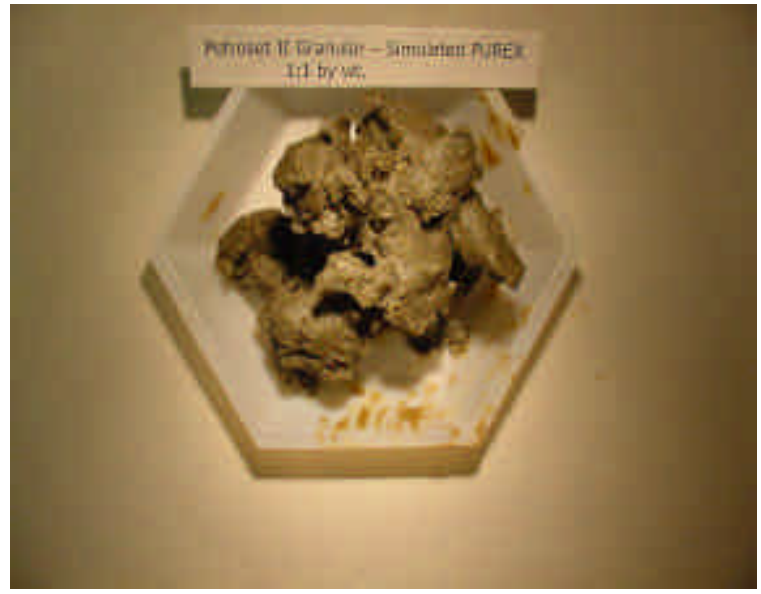

Petroset II Granular

Figure 4-2. Simulated PUREX waste forms with 1:1 absorbent:PUREX waste loadings. 
WSRC-TR-2002-00570, Revision 0

December 3, 2002

Page 15 of 22

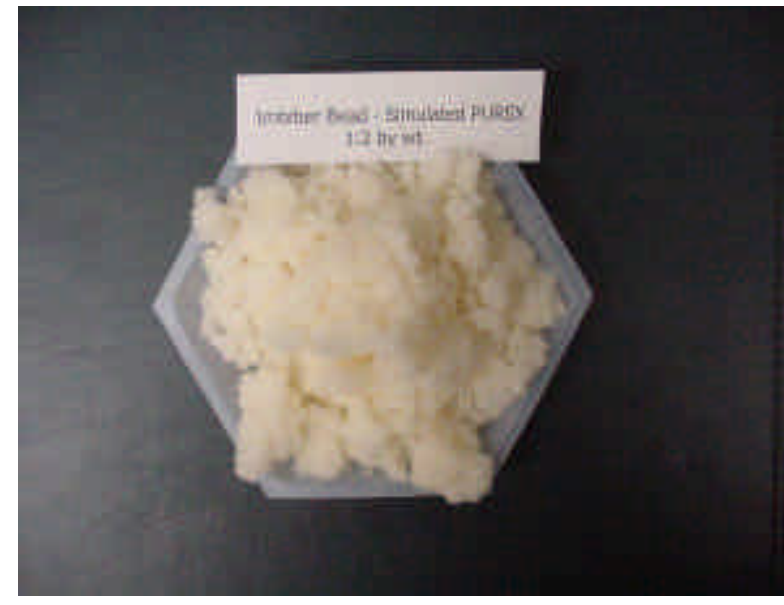

Imbiber

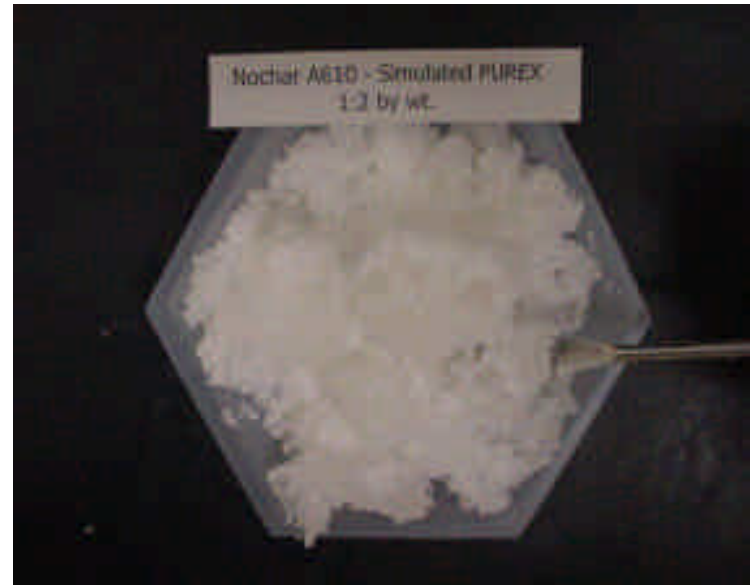

Nochar A610

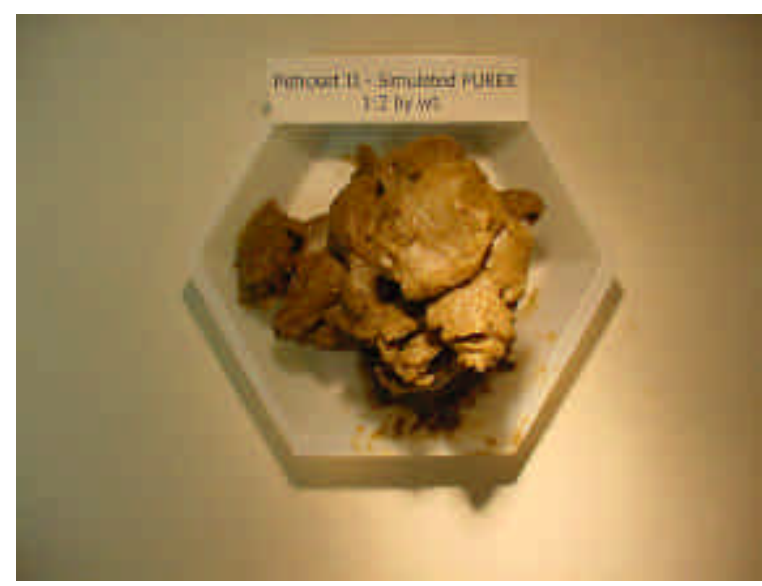

Petroset II

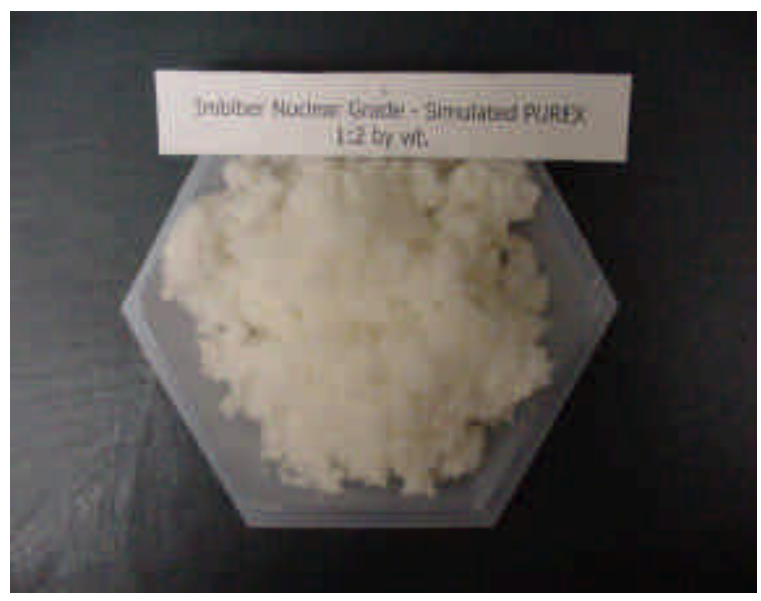

Imbiber Nuclear Grade

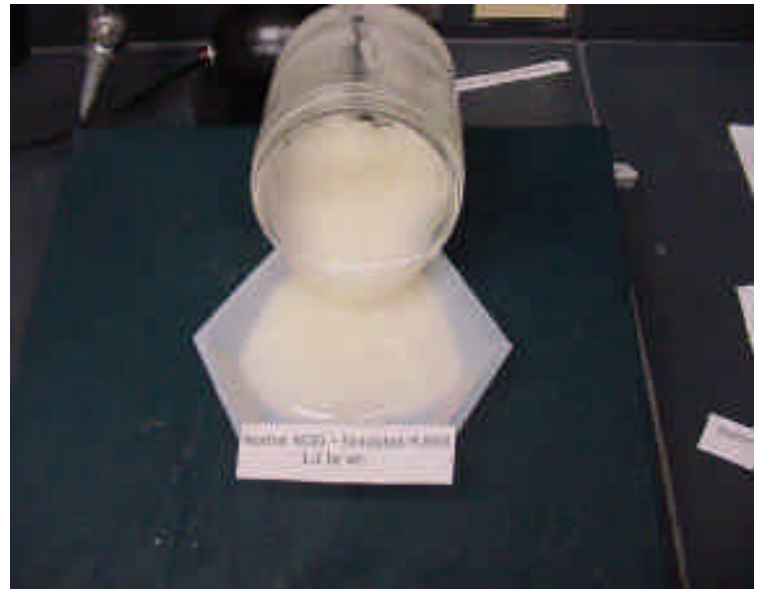

Nochar A650

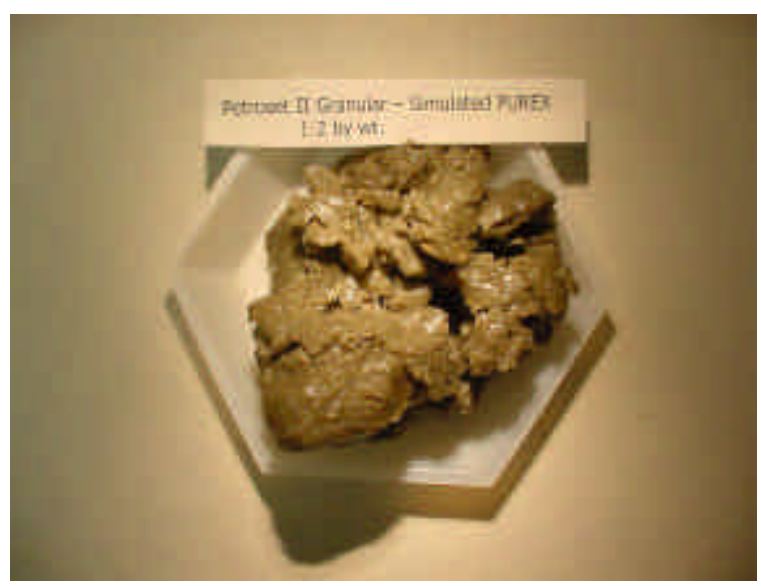

Petroset II Granular

Figure 4-3. Simulated PUREX waste forms with 1:2 absorbent:PUREX waste loadings. 
WSRC-TR-2002-00570, Revision 0

December 3, 2002

Page 16 of 22

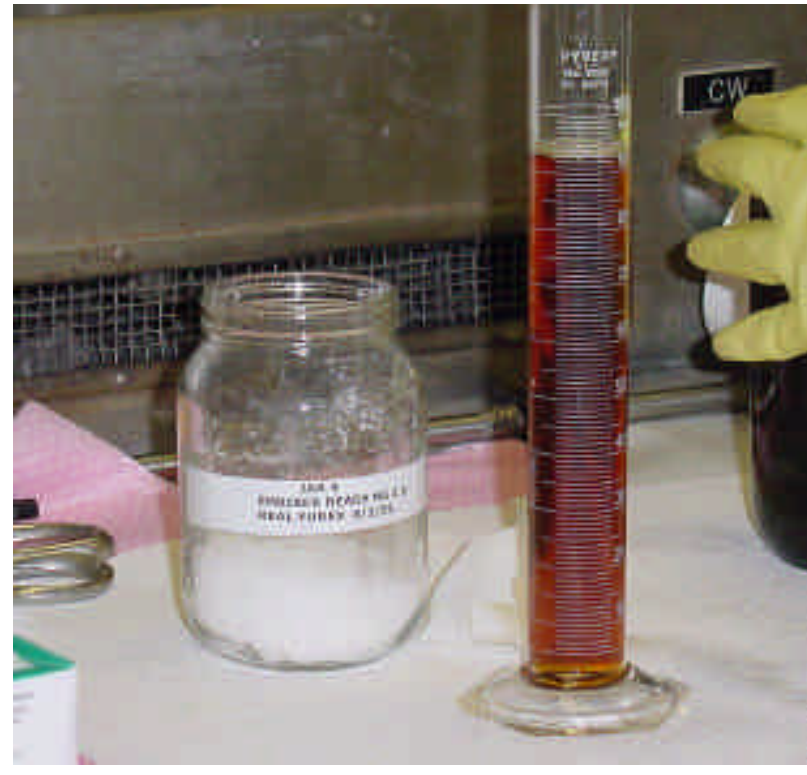

(a) Before Mixing Imbiber NG and Tank 35 Waste (1:2)

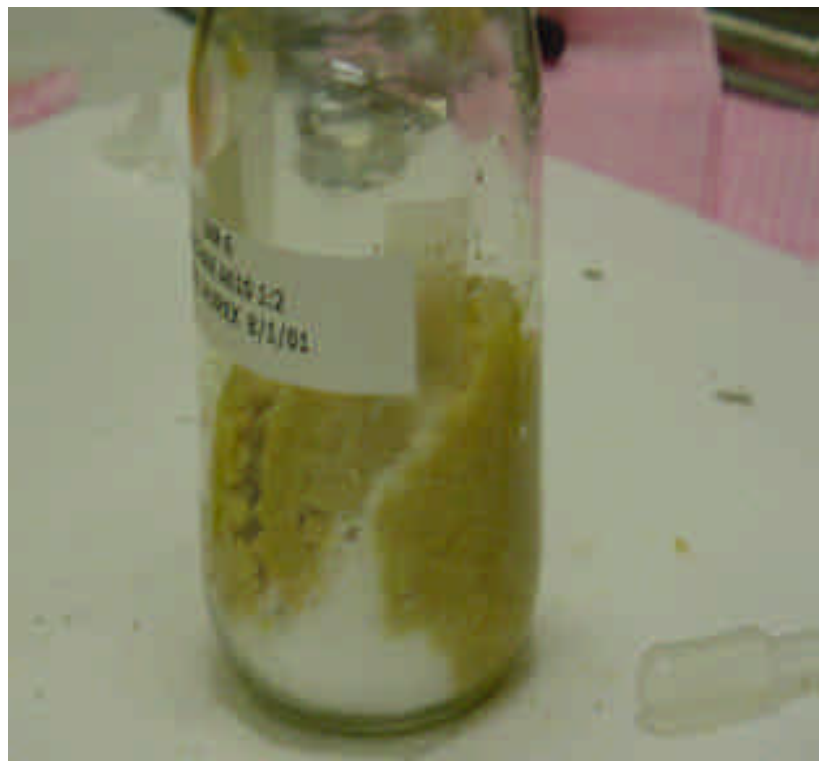

(c) After Addition but Before Mixing Nochar A610 and Tank 35 Waste (1:2)

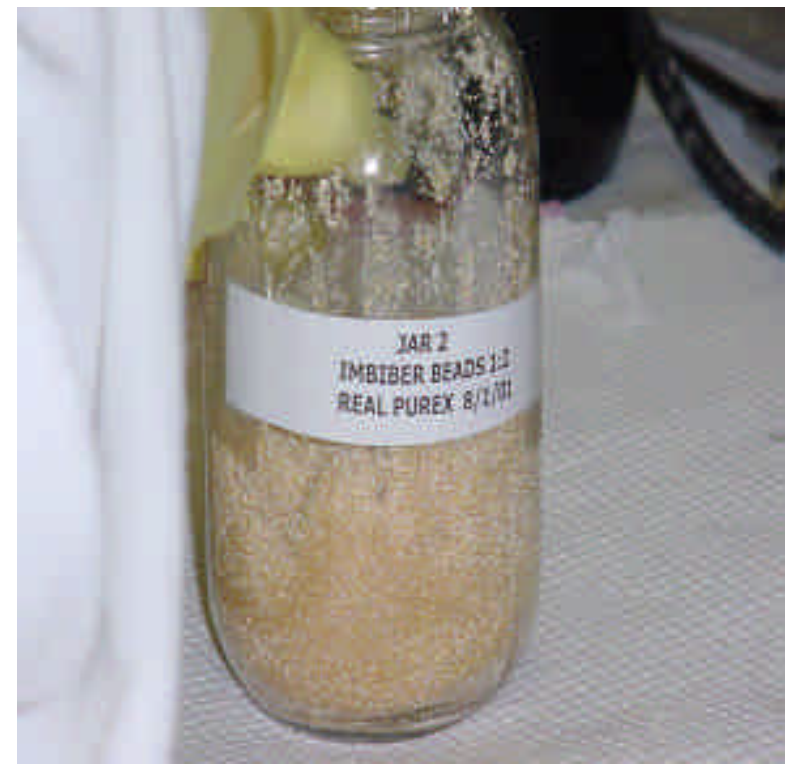

(b) After Mixing Imbiber Beads and Tank 35 Waste (1:2)

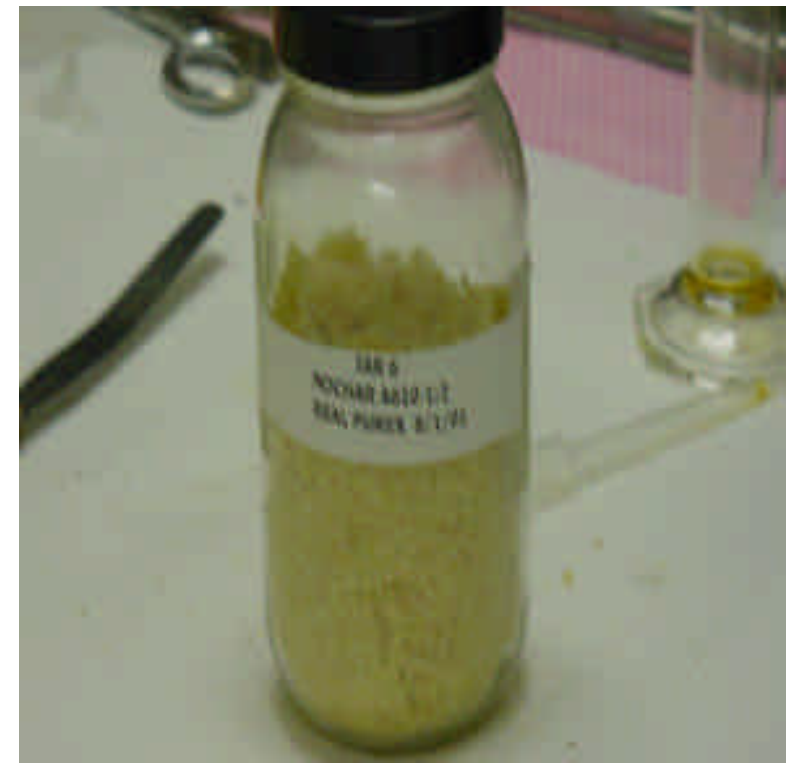

(d) After Mixing Nochar A610 and Tank 35 Waste (1:2)

Figure 4-4. Samples prepared with actual PUREX waste for leaching tests. 
WSRC-TR-2002-00570, Revision 0

December 3, 2002

Page 17 of 22

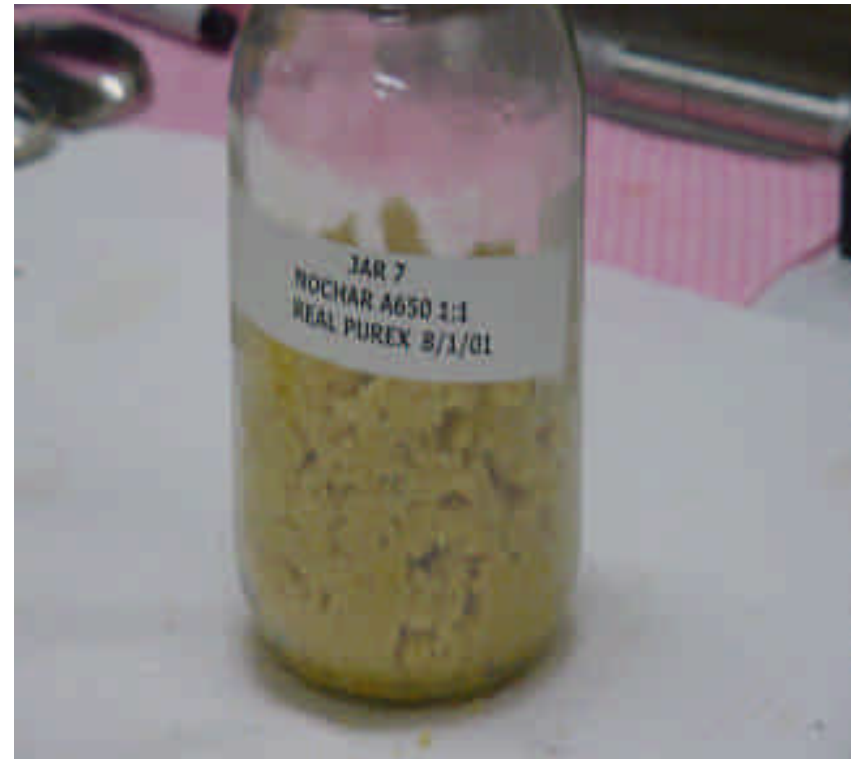

(a) After Addition but Before Mixing Nochar A650 and tank 35 Waste $(1: 1)$

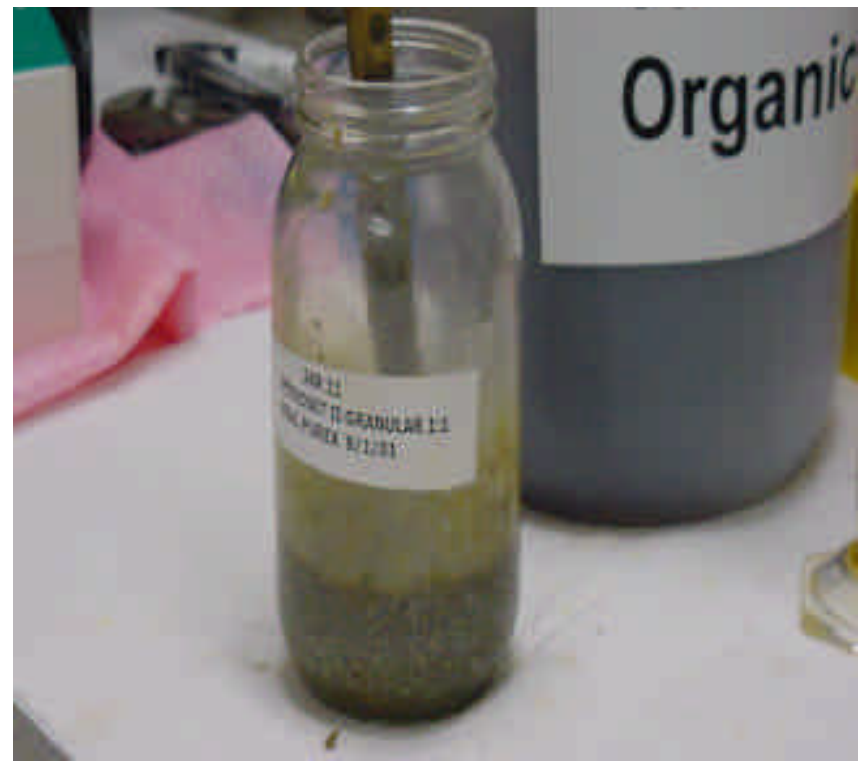

(c) After Addition but Before mixing Petroset II and Tank 35 Waste (1:1)

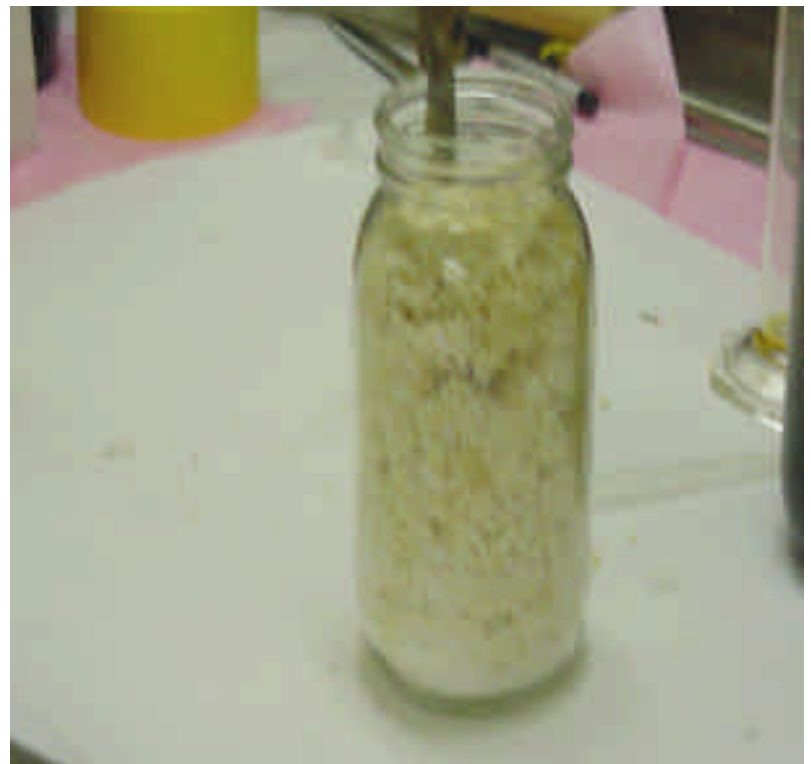

(b) After Mixing Nochar A650 and Tank 35 waste $(1: 1)$

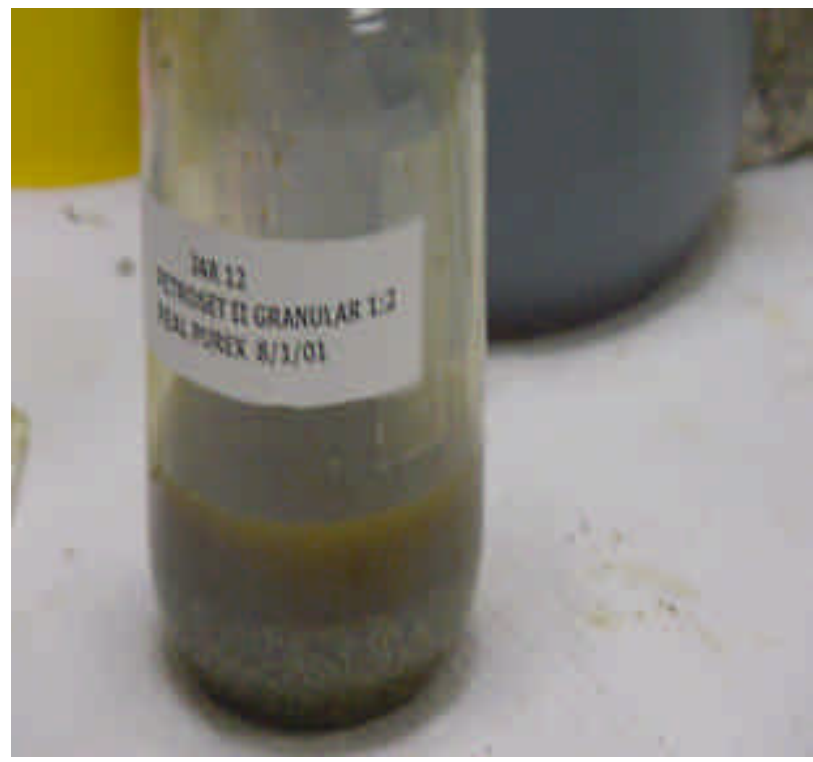

(d) After Addition but Before Mixing Petroset II Granular and Tank 35 Waste (1:2)

Figure 4-5. Samples prepared with actual PUREX waste for leaching tests. 
Given that the organic PUREX waste is classified as characteristically hazardous, in order to exit RCRA regulation the potential for additional Underlying Hazardous Constituents (UHC) must also be evaluated. This evaluation was made by comparing the TCLP leachate results for the identified UHCs (Group II, Columns 2 and 3, Table 4-3) to the UTS limits (Column 6, Table 4-3). This comparison indicates that $\mathrm{Ni}, \mathrm{Sb}$, and $\mathrm{Tl}$ are UHCs and must be treated so that the TCLP leachate concentrations are below the limits identified in Column 6.

In summary, in order to exit RCRA the organic PUREX waste must be treated to:

1. Remove the hazardous characteristics for $\mathrm{As}, \mathrm{Ag}, \mathrm{Ba}, \mathrm{Cd}, \mathrm{Cr}, \mathrm{Hg}, \mathrm{Pb}, \mathrm{Se}$, benzene and TCE (original analysis) toxicity, and

2. Meet the Universal Treatment Standards (UTS) for Ni, Sb, Tl. (See Group II, Underlying Hazardous Constituents in Table 4-3.)

Waste forms prepared by solidifying the PUREX waste were tested to determine whether they met the above requirement. Waste forms with the highest waste loadings (1:2 by weight, i.e., 66 wt. \%) were used for this comparison. The worst case (highest) leachate values for the metals and the highest total values for the organics were listed in Table 4-3, Columns 2 and 3 and Column 7, respectively. In conclusion, all six solidified PUREX waste forms (1:2 waste loadings) meet the requirements to exit RCRA and can be considered for disposal as low-level radioactive waste.

Finally, all analytical data must be certified to satisfy SC DHEC regulations. While SRTC analyses are acceptable for planning and engineering purposes, the final waste form must be analyzed by a certified laboratory in order to be land disposed.

\subsection{TCLP Results}

Results of the waste form TCLP extractions are presented in Table 4-4. The leachate concentrations of the eight D-code metals and the UHC metals qualify the waste forms to exit RCRA. The total benzene and TCE concentrations in the waste forms were also low enough to exit RCRA.

In addition to the waste forms analyzed at SRTC, a Petroset II 1:2 ratio waste form was sent to a certified laboratory (General Engineering Laboratory, Inc.) for an independent TCLP extraction and total benzene analysis to confirm the analytical results. The TCLP results for this waste form, also shown in Table 4-4, are consistent with the SRTC results for all of the waste forms. Treatment was successful in removing the toxicity characteristic from the waste form for the TCLP metals and other inorganic underlying constituents. 
Table 4-3. Summary of the analytical results related to RCRA classification.

\begin{tabular}{|c|c|c|c|c|c|c|}
\hline Column 1 & Column 2 & Column 3 & Column 4 & Col.5 & Column 6 & Column 7 \\
\hline Analyte & $\begin{array}{l}\text { Tank } 33 \\
\text { Organic } \\
\text { Highest } \\
\text { Value(s) } \\
(\mathrm{mg} / \mathrm{L})\end{array}$ & $\begin{array}{l}\text { Tank } 35 \\
\text { Organic } \\
\text { Highest } \\
\text { Value(s) } \\
(\mathrm{mg} / \mathrm{L})\end{array}$ & $\begin{array}{l}\text { TCLP } \\
\text { Haz. } \\
\text { Limit } \\
(\mathrm{mg} / \mathrm{L})\end{array}$ & $\begin{array}{l}\text { RCRA } \\
\text { Codes }\end{array}$ & $\begin{array}{l}\text { LDR } \\
\text { Treatment } \\
\text { Standard } \\
\text { Limit } \\
\text { (mg/L in } \\
\text { TCLP } \\
\text { Leachate) }\end{array}$ & $\begin{array}{l}\text { Worst Case } \\
\text { Total } \\
\text { Concentration in } \\
\text { the PUREX } \\
\text { Waste } \\
(\mathrm{mg} / \mathrm{L})\end{array}$ \\
\hline \multicolumn{7}{|c|}{$\begin{array}{l}\text { Group I. RCRA Hazardous } \\
\text { Constituents }\end{array}$} \\
\hline As & $\begin{array}{l}1.297 \\
1.320 \\
\end{array}$ & $\begin{array}{l}1.368 \\
1.651\end{array}$ & 5 & D004 & 5 & \\
\hline $\mathrm{Ba}$ & $<2$ & $<2$ & 100 & D005 & 21 & \\
\hline $\mathrm{Cd}$ & $<3$ & $<3$ & 1 & D006 & 0.11 & \\
\hline $\mathrm{Cr}$ & 10 & $<7$ & 5 & D007 & 0.6 & \\
\hline $\mathrm{Pb}$ & $<27$ & $<27$ & 5 & D008 & 0.75 & \\
\hline $\mathrm{Hg}$ & $\begin{array}{l}0.9501 \\
0.9802\end{array}$ & $\begin{array}{l}0.4194 \\
0.6280\end{array}$ & 0.2 & D009 & 0.025 & \\
\hline $\mathrm{Se}$ & $\begin{array}{l}0.4505 \\
0.6124\end{array}$ & $\begin{array}{l}0.7850 \\
0.6387\end{array}$ & $<1 *$ & D010 & 5.7 & \\
\hline $\mathrm{Ag}$ & $<6$ & $<6$ & 5 & D011 & 0.14 & \\
\hline Benzene & $<50$ & $<50$ & $\begin{array}{c}0.5 \\
\mathrm{mg} / \mathrm{L} \\
\text { total }\end{array}$ & D018 & $\begin{array}{c}10(\mathrm{mg} / \mathrm{kg}) \\
\text { total }\end{array}$ & $\begin{array}{l}\quad 4.6 \\
\text { ( } 5.6 \mathrm{mg} / \mathrm{kg} \text { total } \\
\text { in the organic } \\
\text { liquid waste) }\end{array}$ \\
\hline $\begin{array}{l}\text { Trichloro } \\
\text { ethylene } \\
\text { (TCE) }\end{array}$ & $<50$ & $<50$ & $\begin{array}{c}0.5 \\
\mathrm{mg} / \mathrm{L} \\
\text { total }\end{array}$ & D040 & $\begin{array}{c}6(\mathrm{mg} / \mathrm{kg}) \\
\text { total }\end{array}$ & $\begin{array}{l}\quad 0.27 \\
(0.33 \mathrm{mg} / \mathrm{kg} \text { total } \\
\text { in the organic } \\
\text { liquid waste })\end{array}$ \\
\hline \multicolumn{3}{|c|}{$\begin{array}{l}\text { Group II. Underlying Hazardous } \\
\text { Constituents }\end{array}$} & & & $\begin{array}{c}\text { UTS Limits } \\
\text { (mg/L in } \\
\text { TCLP } \\
\text { Leachate) }\end{array}$ & \\
\hline $\mathrm{Be}$ & $<1$ & $<1$ & -- & & 1.22 & \\
\hline $\mathrm{Ni}$ & 25 & 15 & -- & & 11 & \\
\hline $\mathrm{Sb}$ & $<64$ & $<63$ & -- & & 1.15 & \\
\hline $\mathrm{Tl}$ & $<129$ & $<129$ & -- & & 0.2 & \\
\hline
\end{tabular}

* If the waste contains $>1 \mathrm{mg} / \mathrm{kg} \mathrm{Se}$, it is hazardous and carries a D-Code regardless of treatment and therefore must be disposed of in a RCRA Subtitle $\mathrm{C}$ landfill. 
Table 4-4. TCLP results and total volatile organic analyses for the organic PUREX waste forms.

\begin{tabular}{|c|c|c|c|c|c|c|c|c|c|}
\hline Analyte & $\begin{array}{c}\text { Imbiber- } \\
\text { Tank } 35 \\
1: 2 \\
\end{array}$ & \begin{tabular}{|c|} 
Imbiber NG- \\
Tank 35 \\
$1: 2$
\end{tabular} & $\begin{array}{c}\text { Nochar A610 } \\
\text { Tank } 35 \\
1: 2 \\
\end{array}$ & $\begin{array}{c}\text { Nochar A650 } \\
\text { Tank } 35 \\
1: 2 \\
\end{array}$ & $\begin{array}{c}\text { Petroset II- } \\
\text { Tank } 35 \\
1: 2 \\
\end{array}$ & \multicolumn{2}{|c|}{\begin{tabular}{|c} 
Petroset II Gran.-Tank \\
35 \\
$1: 2$ \\
\end{tabular}} & $\begin{array}{c}\text { TCLP } \\
\text { Limit } \\
(\mathrm{mg} / \mathrm{L}) \\
\end{array}$ & $\begin{array}{c}\text { UTS } \\
\text { Limit } \\
(\mathrm{mg} / \mathrm{L})\end{array}$ \\
\hline & \multicolumn{9}{|c|}{ (mg/L unless indicated otherwise) } \\
\hline $\mathrm{Ag}$ & $<0.050$ & $<0.050$ & $<0.050$ & $<0.050$ & $<0.050$ & $<0.050$ & $0.0013(U)$ & 5 & 0.14 \\
\hline As & & & & & & & $0.0142(U)$ & 5 & 5 \\
\hline $\mathrm{Ba}$ & 0.649 & 3.61 & 0.701 & 0.537 & 0.510 & 0.560 & $0.0892(U)$ & 100 & 21 \\
\hline $\mathrm{Cr}$ & $<0.012$ & $<0.012$ & $<0.012$ & $<0.012$ & $<0.012$ & $<0.012$ & $\begin{array}{c}0.00281 \\
(U)\end{array}$ & 5 & 0.6 \\
\hline Hg (ug/g) & & & & & & & $\begin{array}{c}0.000362 \\
(U)\end{array}$ & 0.2 & 0.025 \\
\hline $\mathrm{Pb}$ & $<0459$ & $<0.459$ & $<0.459$ & $<0.459$ & $<0.459$ & $<0.459$ & $0.0191(\mathrm{~J})$ & 5 & 0.75 \\
\hline $\begin{array}{l}\text { Benzene } \\
(\mathrm{mg} / \mathrm{kg})\end{array}$ & $5.5 *$ total & $4.5 *$ total & $2.4 *$ total & $0.24 *$ total & $5.5 *$ total & $5.5 *$ total & $0.00483(\mathrm{~J})$ & 0.5 & $10 *$ \\
\hline $\begin{array}{l}\text { Trichloroet } \\
\text { hene } \\
(\mathrm{mg} / \mathrm{kg})\end{array}$ & $\begin{array}{c}0.33^{*} \\
\text { total }\end{array}$ & $0.16^{*}$ total & $0.114 *$ total & $0.007 *$ total & $0.15^{*}$ total & $0.032 *$ total & $0.00(U)$ & 0.5 & $6 *$ \\
\hline $\mathrm{Be}$ & $<0.060$ & $<0.060$ & $<0.060$ & $<0.060$ & $<0.060$ & $<0.060$ & & - & 1.22 \\
\hline $\mathrm{Ni}$ & $<0.090$ & $<0.090$ & $<0.090$ & $<0.090$ & $<0.090$ & $<0.090$ & & - & 11 \\
\hline $\mathrm{Sb}$ & 0.078 & 0.047 & 0.166 & 0.059 & 0.056 & 0.080 & & - & 1.15 \\
\hline $\mathrm{Tl}$ & & & & & & & & - & 0.2 \\
\hline $\mathrm{V}$ & $<0.002$ & $<0.002$ & $<0.002$ & $<0.002$ & $<0.002$ & $<0.002$ & & - & 1.6 \\
\hline $\mathrm{Zn}$ & 0.292 & 1.86 & 0.342 & 0.269 & 0.293 & 0.232 & & - & 4.3 \\
\hline
\end{tabular}

*Total waste form concentrations rather than leachate concentrations.

Results in italics are certified by GEL, Inc., a SCDHEC certified laboratory. J indicates estimated value. The result was greater than the detection limit but less than the reporting limit. U indicates the compound was analyzed for but not detected above the detection limit. 


\subsection{CONCLUSIONS}

Solidification is a promising technology for treating the PUREX organic waste for final disposal. Six sorbents were evaluated at two different waste loadings, 50 and $66 \mathrm{wt} \%$ (1:1 and 1:2 formulations, respectively) selected to stabilize the hazardous constituents in the waste.

The waste form TCLP leaching data for the hazardous metals and the total organic concentrations for benzene and TCE indicate all of the waste forms tested qualify to exit RCRA regulation, and to be disposed of as low-level radioactive solid waste. In addition, the GEL leaching results for benzene and TCE indicate that the organic compounds in the waste are retained in the waste form (stabilized) during the solidification process.

All of the waste forms met the general requirements for disposal as low-level waste in either E-Area/SRS or the Nevada Test Site. However, actual disposal of any new waste stream in E-Area or the NTS requires the generator obtain approval via the SRS Waste Certification process or the NTS Waste Profile acceptance process.

Two organic sorbents, Imbiber Beads and Nochar A610, and two inorganic clay products, Petroset II and Petroset II Granular, warrant further testing. The Imbiber Beads and the Nochar A610 have very rapid absorbencies and require rapid mixing to distribute the PUREX evenly throughout the waste form.

Petroset II Granular sorbent reacts with the PUREX waste much more slowly than Petoset II and the organic polymer sorbents. After initial high-shear mixing, the Petroset II Granular waste forms required about 8 hours to completely absorb the PUREX. The Petroset II is a very fine powder and has a higher surface area. Therefore it absorbs the PUREX much faster than the Petoset II Granular.

Imbiber Beads Nuclear Grade and Nochar A650 were not recommended for further formulation and scale-up testing. The Imbiber Beads Nuclear Grade contains both water and organic liquid sorbents, and swells on contact with water. The polymer sorbents in the Nochar A650 are plasticized (degraded) by components in the PUREX waste (probably the tributylphosphate). 


\subsection{REFERENCES}

1. Langton, C.A. and L.N. Oji, "Task Technical Plan for PUREX Waste Treatability Study," WSRC-RP-2001-00465 Rev. 0, April 18,2001, Savannah River Technology Center, Westinghouse Savannah River Company, Aiken, SC 29801.

2. Procedure Manual 1S SRS Waste Acceptance Criteria Manual, Procedure WAC 3.17 Low-Level Radioactive Waste Acceptance Criteria, Rev. 6, August 01, 2001, Westinghouse Savannah River Company, Aiken, SC 29801.

3. Nevada Test Site Waste Acceptance Criteria - Revision 3, December, 2000, $\mathrm{DOE} / \mathrm{NV}$.

4. Procedure Manual 3B, "Asset Management Manual, Sections 2 and 3" 2001, Westinghouse Savannah River Company, Aiken, SC 29801.

5. Procedure Manual L16.1, Analytical Development Operating Procedure Manual, Savannah River Technology Center, Westinghouse Savannah River Company, Aiken, SC 29801.

6. Site Treatment Plan, WSRC-TR-94-0608, Rev. 9, March 2001, Volume II, p.3-6, Westinghouse Savannah River Company, Aiken, SC 29801. 